\title{
Er drøfting av pasientsaker i klinisk etikk-komiteer nyttig?
}

\author{
Sammendrag \\ Bakgrunn. Alle helseforetak har i dag \\ minst én klinisk etikk-komité (KEK). \\ Disse skal blant annet gi råd og veilede \\ sykehusets ansatte i etiske problem- \\ stillinger. Vi ønsket, som ledd i kvali- \\ tetssikring av arbeidet, å finne ut om \\ klinikerne har hatt nytte av komiteene \\ i enkeltsaker.
}

Materiale og metode. De lokale komiteene ble bedt om å videredistribuere et spørreskjema til alle klinikere som hadde hatt en sak oppe i komiteen i løpet av de siste 18 månedene. Undersøkelsen var anonym. 43 av 86 spørreskjemaer ( $50 \%$ ) som ble delt ut, ble returnert til Senter for medisinsk etikk.

Resultater. De fleste klinikerne hadde flere grunner til å ta kontakt med komiteen. Vanligst var ønsket om å få en bred drøfting av en sak (70\%), noe man fant nyttig. Hyppigste problemstillinger var begrensning i behandlingen av en alvorlig syk ( $56 \%$ ), pårørendes vilje/ønske (40\%) og pasientautonomi (37\%). Komiteen ga råd i $50 \%$ av sakene. $38 \%$ av drøftingene fikk praktiske følger, blant annet endte det i seks tilfeller med behandlingsavslutning.

Fortolkning. Resultatene må fortolkes varsomt pga. lav svarprosent. Komiteenes arbeid blir stort sett vurdert som nyttig, og drøftingene kan få praktiske konsekvenser. Det er en utfordring å gjøre arbeidet kjent blant klinikere og å kvalitetssikre det.

\author{
Guro Kalager \\ Reidun Førde \\ reidun.forde@medisin.uio.no \\ Reidar Pedersen \\ Senter for medisinsk etikk \\ Universitetet i Oslo \\ Postboks 1130 Blindern \\ 0318 Oslo
}

Klinisk etikk-komiteer (KEK) er tverrfaglig sammensatte. Medlemmene har klinisk kompetanse og kompetanse innen etikk (1). Slike komiteer finnes i USA og i de fleste land i Europa. I 2003 besluttet Helse- og omsorgsdepartementet at alle helseforetak skulle ha en etikkomité. Per 1.1. 2009 var det etablert 37 slike i Norge.

Komitéarbeidet skal høyne kompetansen i klinisk etikk og bidra til grundig og systematisk håndtering av etiske problemstillinger (1). Komiteen har ingen beslutningsmyndighet, den skal fungere som beslutningsstøtte og som forum for klinikere og andre berørte parter for drøfting av konkrete etiske problemer, prospektivt eller retrospektivt (1).

Senter for medisinsk etikk (SME) ved Universitetet i Oslo har fått ansvaret for den nasjonale koordineringen av komitéarbeidet og for fagutviklingen. Kvalitetssikring av arbeidet er særlig viktig dersom komiteene skal ha en rolle $\mathrm{i}$ alvorlige beslutninger. Den nasjonale veilederen for beslutningsprosesser angående begrensning av livsforlengende behandling av alvorlig syke og døende anbefaler bruk av etikkomiteene i spesielt utfordrende saker (2).

I 2004 ble det gjennomført et kvalitetssikringsprosjekt der komitémedlemmer og helsepersonell som hadde henvendt seg til etikkomiteene med en pasientsak ble intervjuet (3-6). Alle klinikerne ga uttrykk for at dette hadde vært meningsfylt, men flere sa at terskelen for å søke råd var høy. I noen tilfeller ble henvendelsen sett som illojalitet overfor kolleger (4). Klinikerne verdsatte systematisk og grundig behandling. Det er et gjennomgående problem, ikke bare i Norge, at terskelen for å drøfte en sak i en etikkomité er høy og at komiteene ofte er lite kjent blant klinikere (7). Senter for medisinsk etikk utarbeidet i 2007 en manual for kvalitetssikring og standardisering av komitéarbeidet (8). Evaluering er etterlyst fra flere hold (9-11). Den delen av arbeidet det trolig er viktigst å evaluere, er drøfting av etiske dilemmaer knyttet til behandling av enkeltpasienter. I denne studien har vi undersøkt hvorvidt klinikere som har brukt etikkomiteene til å ta opp enkeltsaker fant dette relevant og nyttig, i tillegg har vi sett på hva slags saker som ble tatt opp og hvordan de ble behandlet.

\section{Materiale og metode}

I mai 2008 sendte Senter for medisinsk etikk en oppfordring til alle landets etikkomiteer om å videreformidle et spørreskjema til alle klinikere som hadde lagt frem saker for komiteen fra og med 2007. Undersøkelsen var anonym, klinikerne skulle kunne besvare spørsmålene uten frykt for at kritiske svar ville komme tilbake til den lokale etikkomiteen eller kollegene. Kritiske kommentarer og innspill ble ansett for å være spesielt verdifulle. Spørreskjemaet ble returnert direkte til Senter for medisinsk etikk. For å få oversikt over svarprosenten ble hver enkelt etikkomité bedt om å melde fra om hvor mange skjemaer de hadde delt ut.

Skjemaet inneholdt 27 spørsmål, blant annet om hvorfor man hadde kontaktet etikkomiteen (tab 1), hvilke etiske problemer det dreide seg om, hvor lenge man måtte vente før saken kom opp og hvilket utfall drøftingen fikk. Dessuten var det flere spørsmål om nytten av komitébehandlingen. Noen av spørsmålene var åpne, noen hadde plass til kommentarer.

Skjemaet var bygd på 2004-undersøkelsen og på internasjonale erfaringer (12).

\section{Resultater}

20 etikkomiteer hadde videreformidlet 86 spørreskjemaer. 43 skjemaer ble returnert til Senter for medisinsk etikk (50\%). Ikke alle spørsmål var besvart i alle skjemaene.

Hvem kontakter etikkomiteen?

$23(54 \%)$ av dem som hadde henvendt seg til komiteen var leger, 15 (35\%) var sykepleiere og to $(5 \%)$ var psykologer. Tre personer $(7 \%)$ hadde en annen profesjon. To

\section{Hovedbudskap}

- Klinikere fant det nyttig å ta opp etiske problemstillinger i en etikkomité

- Flere av drøftingene fikk praktiske følger

- Pasienter og pårørende var i liten grad brakt direkte inn i drøftingen 
(5\%) av drøftingene hadde komitémedlemmene selv initiert.

Tabell 2 gir en oversikt over avdelingstilhørigheten til de drøftede pasientene psykiatrisk avdeling, medisinsk/nevrologisk avdeling og intensivavdeling var hyppigst representert.

$51 \%$ av sakene ble drøftet før en beslutning var tatt (prospektivt), 49\% etterpå (retrospektivt).

\section{Hvorfor ble etikkomiteen kontaktet?}

Tabell 3 viser hvilke etiske problemer som ble definert. Vanligst var begrensning av behandling av alvorlig syk, pårørendes vilje/ ønske og pasientautonomi.

Nesten alle som kontaktet etikkomiteen, oppga at det var flere årsaker til henvendelsen (tab 1). 30 personer $(70 \%)$ svarte at de ønsket en bred drøfting av saken, 25 (58\%) ville ha et «blikk utenfra». Flere kommenterte at behandlingen hadde belyst sakens kompleksitet og gitt et bredere grunnlag for å ta en beslutning. 22 deltakere $(51 \%)$ hadde kontaktet komiteen for å få råd om hvilken beslutning de skulle ta - 17 av disse sakene var prospektive. $16(37 \%)$ ville ha støtte for en avgjørelse de allerede hadde tatt, av disse sakene var det ti prospektive. Én syntes det var godt å få støtte for en beslutning som de pårørende hadde vært uenig $i$, men kommenterer at det var vel så viktig at disse ble hørt av en tredje instans uten behandlingsansvar. Det var med på å sikre en mer åpen prosess. Det var generelt få negative tilbakemeldinger, men en lege som ikke fikk støtte for sin avgjørelse skrev: «Det virket som en slags rettssak hvor jeg skulle stå til rette. Jeg opplevde det som en ekstrem vilje til å følge pasientens vilje, og manglende forståelse for at pasienter ikke alltid vet sitt eget beste.»

Vi spurte også klinikerne om hvor nyttig diskusjonen hadde vært (tab 1). Nytten hadde vært størst der de trengte råd for å kunne ta en beslutning, ønsket en bred drøfting av saken, syntes det var godt å få et «blikk utenfra» og der de ville være bedre rustet for liknende saker i fremtiden. Dette var også blant de viktigste årsakene til at de hadde kontaktet etikkomiteen.

Komiteens bidrag til bedre samarbeid og konflikthåndtering var noe $\mathrm{av}$ det klinikerne var minst fornøyd med.

\section{Prosedyrer}

30 personer $(73 \%)$ hadde gitt skriftlig informasjon om saken til komiteen før drøftingen, åtte av komiteene ( $20 \%$ ) hadde formøte med folk som kunne gi opplysninger, åtte deltakere $(20 \%)$ svarte at alle impliserte var til stede under behandlingen og to hadde formidlet opplysninger om saken gjennom et intervju på forhånd.

Ti personer $(23 \%)$ sa at det gikk få dager fra de henvendte seg til komiteen til drøftingen fant sted, sju (16\%) hadde ventet i maks to uker, $11(26 \%)$ hadde ventet i $2-4$ uker og $15(35 \%)$ ventet i mer enn fire uker.
Tabell 1 Årsaker til at klinikerne ( $n=43$ ) kontaktet etikkomiteene og deres vurdering av hvor nyttig drøftingen var ut fra årsaken til at de tok kontakt ( 1 = ikke nyttig, 5 = svært nyttig)

\begin{tabular}{cc}
$\begin{array}{c}\text { Arsak til } \\
\text { at komiteen } \\
\text { ble kontaktet }\end{array}$ & $\begin{array}{c}\text { Hvor nyttig } \\
\text { var drøftingen } \\
\text { (1-5-skala)? }\end{array}$ \\
$\begin{array}{c}\text { Antall (\%) } \\
30(70)\end{array}$ & $\begin{array}{c}\text { Antall (skår) } \\
25(4,1)\end{array}$ \\
26 (61) & $20(3,7)$ \\
$25(58)$ & $18(4,1)$ \\
$25(58)$ & $19(4,1)$ \\
$22(51)$ & $20(4,1)$ \\
\hline $21(49)$ & $16(3,9)$ \\
$16(37)$ & $15(3,4)$ \\
\hline $10(23)$ & $7(3,7)$ \\
\hline $9(21)$ & $3(2,0)$ \\
$7(16)$ & $4(3,5)$ \\
$5(12)$ & $4(3,3)$ \\
$4(9)$ & $2(4,0)$ \\
\hline $4(9)$ & $4(3,3)$ \\
$4(9)$ & $4(3,3)$ \\
\hline $5(12)$ & $3(3,3)$ \\
\hline
\end{tabular}

11 av dem som ventet $\mathrm{i}$ over fire uker hadde en retrospektiv sak.

37 av klinikerne $(86 \%)$ sa at ventetiden var akseptabel.

Etter drøftingen mottok 33 deltakere ( $77 \%)$ et referat. Åtte $(27 \%)$ arkiverte dette i pasientens journal, åtte $(27 \%)$ nedtegnet konklusjonen i journalen og 17 (57\%) arkiverte referatet blant egne dokumenter.

\section{Deltakere under drøftingen}

31 respondenter $(76 \%)$ oppga at hele komiteen/de fleste komitémedlemmene deltok i drøftingen og åtte (20\%) at noen (2-4 medlemmer) deltok. I én av sakene deltok bare ett medlem. 27 av klinikerne (63\%) hadde selv vært til stede under hele behandlingen. Av de 15 som ikke hadde vært til stede, ville seks gjerne ha vært med.

Tabell 4 gir en oversikt over hvem som, i tillegg til komitémedlemmene, deltok under drøftingen. Ti respondenter mente at andre også burde ha vært med, f.eks. jurist, sosionom, fagspesialist, pasientansvarlig lege og pårørende.

I gjennomsnitt deltok 9,4 personer under drøftingen (spredning 4-20).

\section{Deltakelse av pasient/pårørende}

Ingen pasienter var med under drøftingene (tab 4), i fem av sakene deltok pårørende. I én sak var pårørende invitert, men møtte ikke.

Av de fem klinikerne som hadde hatt med pårørende, sa tre at det hadde vært uproblematisk og positivt. En kommenterte: "Godt å vise at hele pasienten var tydelig i fokus.» Alle fem hadde følt at de kunne snakke fritt og at det faglige var blitt tydeliggjort godt nok. Én mente imidlertid at et motsetningsforhold til de pårørende hadde hemmet den etiske drøftingen og at møtet hadde ført til høyere konfliktnivå.

\section{Utfall}

Av de 42 som besvarte dette spørsmålet, sa $21(50 \%)$ at etikkomiteen hadde gitt et entydig råd. Blant annet ble fire anbefalt å avstå

Tabell 2 Hvilken avdeling tilhørte pasienten som ble drøftet i komiteen $(n=43)$ ?

\begin{tabular}{lc} 
& Antall (\%) \\
\hline Psykiatrisk avdeling & $12(28)$ \\
\hline Medisinsk/nevrologisk avdeling & $10(23)$ \\
\hline Intensivardeling & $6(14)$ \\
\hline $\begin{array}{l}\text { Gynekologisk, kirurgisk } \\
\text { eller onkologisk avdeling }\end{array}$ & $6(14)$ \\
\hline Nyfødtavdeling/barneavdeling & $5(12)$ \\
\hline Annen & $4(9)$ \\
\hline
\end{tabular}

Tabell 3 Hvilke etiske problemer ble definert under drøftingen ( $\mathrm{n}=43$ )?

Antall (\%)

Behandlingsbegrensning

av alvorlig syk

Pårørendes vilje/ønske

Pasientautonomi

Tvang overfor pasient

Prioritering/ressurser

Informasjon/kommunikasjon

Taushetsplikt

Etiske problemer knyttet

til reproduksjon

Annet 
Tabell 4 Hvilke andre, foruten medlemmer av etikkomiteen, deltok under drøftingen $(n=33)$ ?

Antall (\%)

Sykepleier/pleiepersonell

Leger med relevant

fagkompetanse

$21(64)$

Avdelingsledelse

Pårørende

En som representerte pasienten

Pasienten

0

Andre

fra videre behandling/avslutte pågående. To av rådene gjaldt bruk av tvang, og to klinikere fikk råd om å søke annenhåndsvurdering eller henvende seg til fylkeslegen.

12 klinikere (31\%) følte det kom noe nytt frem under drøftingen, blant annet prinsipper for behandling av liknende saker i fremtiden.

15 klinikere (38\%) oppga at drøftingen fikk praktiske følger - i seks av tilfellene førte den til at man avsto fra videre behandling/avsluttet pågående. En annen skriver at komitébehandlingen fikk betydning i den forstand at etiske hensyn senere ble bedre ivaretatt.

To besvarte spørsmålet om hvorfor den endelige beslutningen ikke fulgte komiteens konklusjoner. De sa at hensyn til de pårørende, uenighet innad i behandlingsteamet, press fra advokater/medier og nye opplysninger som kom frem spilte inn.

\section{Diskusjon}

Det er flere årsaker til at det er viktig å evaluere etikkomiteenes arbeid. Det skal være et troverdig tilbud som kan bidra til bedre pasientbehandling, og det bør tilpasses brukernes behov i størst mulig grad. Tilbudet må også evalueres for å rettferdiggjøre ressursbruken.

I denne studien har vi henvendt oss til helsepersonell som har lagt frem enkeltsaker for en etikkomité. Pasientens og de pårørendes perspektiv er ikke representert. Studier foretatt $i$ andre land har vist at helsepersonell ofte er mer tilfreds med komitébehandling av vanskelige saker enn pasient og pårørende er $(13,14)$. Flere internasjonale studier viser at helsepersonell finner drøfting $\mathrm{i}$ en etikkomité nyttig (13-15). Det er å håpe at man gjennom dette også sikrer at pasientens beste ivaretas. Men drøftingen kan være viktig også i tilfeller der klinikerne ikke får full støtte for alt de har tenkt.

\section{Hvem bør delta i drøftingen?}

De norske komiteene arbeider forskjellig. Vi finner at det ikke er rutine å invitere alle involverte parter til drøftingen. Ingen pasienter deltok, og pårørende deltok $\mathrm{i}$ kun $15 \%$ av sakene. Vi vet ikke om dette er for å skåne dem for informasjon som kan skape engstelse eller om det skyldes bekymring for at deres tilstedeværelse vil legge lokk på diskusjoner om vanskelige medisinske og etiske spørsmål (8). Mange etikkomiteer oppfatter nok helsepersonell som sin primære målgruppe.

Kommunikasjonsproblemer og konflikt står ofte sentralt når en sak er etisk utfordrende for klinikeren $(8,13)$. Der det er uenighet, bør ikke én part representere den andre partens syn. Dette taler for å involvere pasient, pårørende eller annen som representerer pasienten, særlig i prospektive saker. I retrospektive saker, hvor læringsperspektivet står mer sentralt, er det ikke like viktig at pasienten er direkte eller indirekte representert. Men komiteen må alltid sørge for at pasientens og de pårørendes perspektiv blir tilstrekkelig belyst og vektlagt. Deres deltakelse vil kunne bidra til at alle får større forståelse for sakens kompleksitet, og det kan gi dem trygghet for at de blir tatt alvorlig (16). I studien vår er det verdt å merke seg at klinikerne stort sett fant det uproblematisk og positivt å ha pårørende med i drøftingen.

Av de klinikerne som ikke selv deltok i drøftingen, var det flere som skulle ønske at de hadde vært invitert. Deltakelse fra alle parter kan klargjøre usikkerhet og uenighet knyttet til fakta og bidra til bedre dialog (16).

\section{Lavterskeltilbud}

Undersøkelsen i 2004 viste at mange komiteer har få saker $(5,6)$. Det er en kontinuerlig utfordring for komiteene å bli bedre kjent på sykehusene. Studier har vist at det er en høy terskel i den medisinske kulturen for å drøfte problemer med utenforstående, og mange klinikere er redd for kritikk $(5,6)$. En etikkomité skal være et lavterskeltilbud for å fremme evnen til etisk refleksjon, ikke et forum for moralisme og domfelling (8).

For mange travle klinikere er det viktig at tilgjengeligheten til etikkomiteenes tjenester sikres og at det er kort ventetid fra henvendelse til drøfting. Undersøkelsen vår viste at $35 \%$ ventet mer enn fire uker, men dette var stort sett i retrospektive saker. Mange komiteer kan møtes på kort varsel.

Etikkomiteene har tidligere fått kritikk for manglende prosedyrer og for at behandlingen ikke er strukturert nok (5). Få har kommentert dette i denne undersøkelsen. $77 \%$ fikk referat fra drøftingen, etter vår mening bør alle impliserte få. Dette krever ressurser, men referat sikrer åpenhet og innsyn.

\section{Utfall og nytte}

Et viktig spørsmål er hva som avgjør om drøfting av en sak i en etikkomité oppfattes som nyttig. Undersøkelsen viste at komiteene hadde gitt entydige råd $i$ bare halvparten av sakene. Vanligste årsak til at klinikere tok kontakt, var ønsket om bred behandling. Sakene som tas opp i etikkomiteene er ofte komplekse, og det er ikke alltid mulig å peke på den eneste rette løsningen. I siste instans må behandlingsansvarlig lege fatte en be- slutning. Drøfting i etikkomiteen kan være en støtte i dette, ved at de etiske sidene av en kompleks sak blir belyst.

Undersøkelsen viser også at drøftingene fikk praktiske følger i 15 saker $(38 \%)$ - i seks av disse avsto man fra videre behandling eller avsluttet pågående. At komitéarbeidet har innflytelse i alvorlige beslutningsprosesser, understreker behovet for kvalitetssikring.

\section{Begrensninger}

Undersøkelsen har flere begrensninger. Materialet er lite, og vi har en svarprosent på 50 . Undersøkelsen var anonym fordi vi var spesielt interessert i kritiske tilbakemeldinger. Dette innebar at vi ikke kunne purre direkte til klinikerne som hadde fått skjemaet. Senter for medisinsk etikk har nasjonalt ansvar for å styrke kvaliteten av arbeidet. Det at besvarte skjemaer ble sendt direkte dit, kan ha påvirket svarene i positiv retning. Vi kan heller ikke utelukke at etikkomiteene har gitt skjemaet til de klinikerne de antok var fornøyde.

$\mathrm{Vi}$ vet ikke hvor mange saker komiteene har drøftet totalt i denne perioden. Den enkelte komité har ingen plikt til å sende årsmelding til Senter for medisinsk etikk, selv om de fleste gjør det. Vi vet ikke hvorfor så mange komiteer ikke videreformidlet spørreskjemaet. Senter for medisinsk etikks årsrapport for 2009 viste at en firedel av komiteene ikke hadde drøftet saker relatert til enkeltpasienter det siste året (17). For slike komiteer vil ikke vår undersøkelse være relevant. En annen grunn til lav deltakelse kan være at undersøkelsen ble satt i gang like før sommerferien. Vi kan altså ikke være sikre på om respondentene våre er representative for klinikerne som har benyttet etikkomiteene og om resultatene er generaliserbare. Vår undersøkelse kan betraktes som en pilotstudie - en mer systematisk og representativ gjennomgang bør gjøres senere.

\section{Konklusjon}

Undersøkelsen tyder på at helsepersonell som har benyttet etikkomiteer i enkeltsaker syntes det var nyttig. I en tid der stadig mer blir mulig innenfor medisinen, vil det dukke opp nye etiske utfordringer. Etikkomiteene kan bidra positivt i slike saker ved å sikre at alle involverte parter blir hørt og ved å belyse alle sakens sider - og slik bidra til etisk akseptable beslutninger.

Oppgitte interessekonflikter: Ingen

\section{Litteratur}

1. Informasjon til komiteer i etableringsfase. Oslo: Seksjon for medisinsk etikk, Universitetet i Oslo, 2008. www.med.uio.no/iasam/sme/kek/ komiteene/etablering/ (10.12.2010).

2. Nasjonal veileder for beslutningsprosesser for begrensning av livsforlengende behandling hos alvorlig syke og døende. Oslo: Helsedirektoratet, 2009. www.helsedirektoratet.no/publikasjoner/veiledere/nasjonal veileder for

beslutningsprosesser_for_begrensning_av ivsforlengende_behandling_hos_alvorlig_syke_og d_ende_400374 (10.12.2010). 
3. Pedersen R, Førde R. Hva gjør de kliniske etikkomiteene? Tidsskr Nor Lægeforen 2005; 125: 3127-9.

4. Pedersen R, Akre V, Førde R. What is happening during case deliberations in clinical ethics committees? A pilot study. J Med Ethics 2009; 35: 147-52.

5. Førde R, Pedersen R, Akre V. Clinicians' evaluation of clinical ethics consultations in Norway: a qualitative study. Med Health Care Philos 2008; 11 . $17-25$.

6. Pedersen R, Akre V, Førde R. Barriers and challenges in clinical ethics consultations: the experiences of nine clinical ethics committees. Bioethics 2009; 23: 460-9.

7. Fox E, Myers S, Pearlman RA. Ethics consultation in United States hospitals: a national survey. Am J Bioeth 2007; 7: 13-25.

8. Manual for arbeidet i klinisk etikk-komité. Oslo: Seksjon for medisinsk etikk, Universitetet i Oslo, 2007. www.med.uio.no/iasam/sme/kek/manual/ (10.12.2010)

9. Williamson L. Empirical assessments of clinical ethics services: implications for clinical ethics committees. Clin Ethics 2007; 2: 187-92.

10. Craig JM, May T. Evaluating the outcomes of ethics consultation. J Clin Ethics 2006; 17: 168-80.

11. Pfäfflin M, Kobert K, Reiter-Theil S. Evaluating clinical ethics consultation: a European perspective. Camb Q Healthc Ethics 2009; 18: 406-19.

12. Fletcher JC, Siegler M. What are the goals of ethics consultation? A consensus statement. J Clin Ethics 1996; 7: 122-6.

13. McClung JA, Kamer RS, DeLuca M et al. Evaluation of a medical ethics consultation service: opinions of patients and health care providers. Am J Med 1996; 100: 456-60.

14. Yen BM, Schneiderman LJ. Impact of pediatric ethics consultations on patients, families, social workers, and physicians. J Perinatol 1999; 19 373-8.

15. Cohn F, Goodman-Crews P, Rudman W et al. Proactive ethics consultation in the ICU: a comparison of value perceived by healthcare professionals and recipients. J Clin Ethics 2007; 18: 140-7.

16. Førde R, Hansen TW. Involving patients and relatives in a Norwegian clinical ethics committee: what have we learned? Clinical Ethics 2009; 4: 125-30.

17. Årsrapport 2009. Kliniske etikk-komiteer. Oslo: Seksjon for medisinsk etikk, Universitetet i Oslo, 2010. www.med.uio.no/iasam/sme/kek/om/ arsmeldinger/2009/aarsrapport-2009.pdf (8.7.2010).

Manuskriptet ble mottatt 10.2. 2010 og godkjent 27.7. 2010. Medisinsk redaktør Erlend Hem. 